REVIEWS

DR DAVID ROBIE is editor of Pacific Journalism Review.

\section{Merdeka: Media and the case for Papuan civil resistance}

Merdeka and the Morning Star: Civil resistance in West Papua, by Jason MacLeod. St Lucia: University of Queensland Press. 2015. 284 pp. ISBN 978-0-7022-5376-8

EIVE years ago the Pacific Media F Centre and Pacific Media Watch published a 'state of media freedom report' - the first such documentation in the Pacific region-and the most devastating section was about West Papua (Perrottet \& Robie, 2011, 2012). The harrowing account of human rights violations and abuses of freedom of speech by the Indonesian military and security forces eclipsed comparable reports from the Pacific, including Fiji which was at the time a cause célèbre for free press champions.

The theme of this report echoed many articles I have written over the years highlighting the 'black' or 'blind spot' demonstrated by New Zealand media neglect of covering West Papua and the self-determination cause (see Robie, 2011). Since then much has changed.

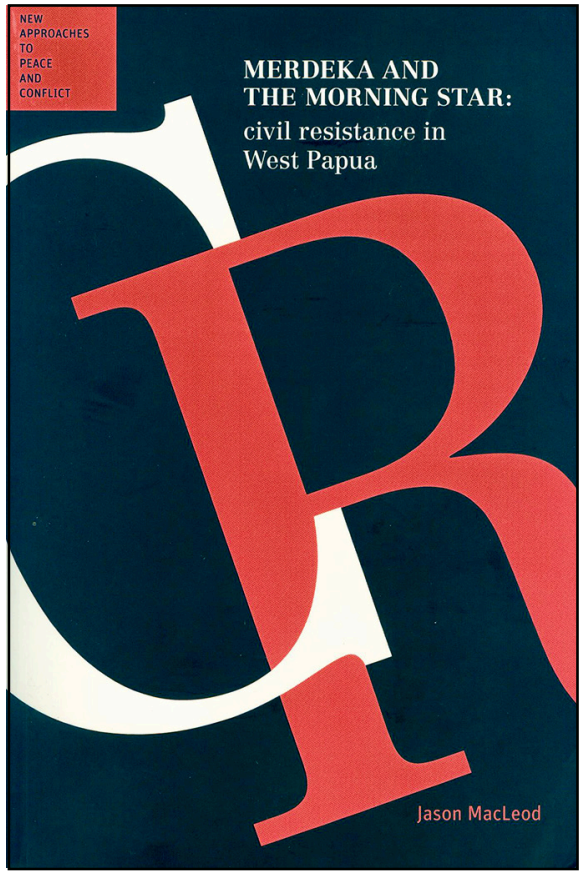

A New Zealand journalist, Paul Bensemann, went undercover to West Papua in 2013 and reported on accusations over New Zealand 'aid that kills' in the region (Bensemann, 2014). This was followed up in 2015 by both Māori Tele vision's Native Affairs reporter Adrian Stevanon (with researcher Karen Abplanalp) - the first NZ TV crew to visit West Papua in a half century (MTS, 2015) - and Radio New Zealand's Johnny Blades and Koroi Hawkins (RNZ, 2015) taking up the challenge of President Joko Widowo's controversial pledge to 'open up' West Papua to the world's media. But the rest of the New Zealand media has remained unmoved.

It is thus refreshing and timely to welcome Australian educator, journalist, organiser and researcher Jason MacLeod's new book, Merdeka and the 
Morning Star: Civil resistance in West Papua, based on his doctoral thesis and 14 years of research in the region. This is essential reading for journalists, civil society activists and policymakers concerned over West Papua and a peaceful future for the Pacific.

It recounts five decades of Indonesian oppression, but it is also a comprehensive analysis of hopes and possibilities for the future.

Ironically, 2011 - the year of the Pacific media freedom report on Papua - heralded a dramatic growth of citizen journalism and social media exposure of the West Papuan cause on the global stage. Since then, international media and public interest has grown sharply-even if it remains muted in New Zealand-leading to the historic inclusion of West Papua as an observer with the Melanesian Spearhead Group (MSG) in the Solomon Islands in 2015.

Although I was highly critical of Fiji and Papua New Guinea on my media blog Café Pacific over their 'betrayal' of the Melanesian cause at the time, inspired leadership by host Prime Minister Manasseh Sogavare in Honiara ultimately proved decisive (Robie, 2015).

As MacLeod recounts, faced with intransigence by the Jakarta government, Papuan leaders 'escalated tactics':

On the last day of the Third Papuan People's Congress - a three-day gathering of unarmed resistance groups in October 2011-Papuan leaders formed the NFRWP (National Federal Republic of West Papua) and declared independence. The response from the security forces was swift and brutal. About an hour after the congress concluded, the security forces opened fire. Three Papuans were shot dead. Two were fatally stabbed. Three hundred people were arrested and beaten. Six leaders were jailed, charged with treason. The police-who shot, stabbed, beat and tortured people-received warning letters (p. 155).

The killing of protesters at the congress - reported widely internationally by mobile phone, Facebook, YouTube and activist emailing lists - stirred anger among Papuans, both at home and abroad, and shocked international supporters. PMC Online reported the outrage at the time with embedded footage even though the killings were largely ignored by the New Zealand media (PMC Online, 2011).

According to MacLeod, the attack by the Indonesian forces on unarmed Papuans and an earlier occupation of the provincial parliament in June 2010 'were also evidence that the social media revolution had well and truly arrived in West Papua'.

MacLeod contrasts these events with the Biak massacre in July 1998 when the Indonesian military opened fire on activists who had been protesting for days, raising the Morning Star and singing songs of independence, when more than 100 people were killed, raped or tortured (Peacock, 2013). A leader, Filep Karma, was jailed for 15 years for raising the free Papuan flag.

'It took weeks and months for the news to get out,' notes MacLeod. 'Even 
now we do not have a comprehensive forensic account of what happened' in spite of the Elsham Papua investigation (1999) and 'Bloody Biak' report. After the October 2011 shootings and reprisals, "the news was instantaneous, even though no international journalists were present' (p. 155)

MacLeod refers to the 'surprising announcement' by President Widodo that foreign journalists would become free to visit West Papua, but qualifies this with the observation: 'As long as the Indonesian government values propaganda over a free press, the battle for open access to West Papua will be ongoing.' He notes that the Surat Jalam system through which police and intelligence services monitor foreign visitors remains in force (p. 156).

The main thrust of MacLeod's book is making a case for nonviolent civil resistance by Papuans and their international supporters, saying that the armed struggle has achieved little, whereas some significant gains have been made by mass mobilisation and civil disobedience.

The book is divided into six chapters as well as a prologue, epilogue and postscript (updating the struggle) with a 'Now we take our message to the world' theme. Chapter one outlines the research framework and methodology, two examines the historical and political dynamics of the conflict, three offers alternative visions of merdekafreedom and what it means for West Papua, four looks at civil resistance, five outlines the transition from armed to unarmed resistance, while chapter six provides a framework for 'nonviolent liberation'.

In the final chapter, MacLeod highlights successful campaigns of nonviolent resistance ranging between localised struggles like the Freeport mineworkers strikes in 2007 and 2011 and the unified push for membership of the MSG that is 'accelerating the internationalisation of the struggle' (p. 192). Some specific examples he cites are:

- Papua Land of Peace campaign for inter-communal harmony and peaceful dialogue.

- Hand Back Otsus (failed special autonomy status) campaign.

- The devastating Freeport-McMoRan mine strikes and the Tongoi Papua campaign.

- Public declaration of independence in October 2011.

- The campaign to become members of the MSG.

The author also highlights the successful Mama-Mama campaign by women traders to secure their own marketplace in the heart of Jayapura, and the shutdown of BHP Billiton's planned Gag Island mine by environmentalists, indigenous and human rights campaigners. Ongoing actions to release political prisoners in West Papua and to support open media access also get strong support in this book.

MacLeod also points out the reality of how civil resistance threatens vested interests and is highly critical of a narrow view of 'economic development' as imposed by Jakarta without consultation with the Papuans. 
It undermines Jakarta's legitimacy, and imposes heightened economic and political costs on the Indonesian state. Newfound international interest is starting to provoke greater political attention from Jakarta. It is also clear that solutions focused solely on economics will not fix the problem just as economic progress has not quelled the clamour for independence in Kanaky (New Caledonia) (p. 193).

While conceding that conditions are currently not favourable for a fully independent West Papua, MacLeod presents an argument for greater people's mobilisation and the growth of citizen media that could still achieve much. Papuans need to emphasise their ethnic distinctiveness 'without falling prey to narrow ethno-nationalism'. He points out that while the international system of states is 'far from unraveling', after independence in East Timor, Kosovo, South Sudan and the breakdown of Syria and Iraq, some post-colonial boundaries are perhaps more shaky than they used to be.

So, while an independent West Papua appears highly unlikely, it would be presumptuous to think it will never happen (p. 232).

\section{References}

Bensemann, Paul (2014, January 27). New Zealand accused of providing 'aid that kills' in West Papua. Pacific Media Centre Online. Retrieved at www.pmc. aut.ac.nz/articles/new-zealand-accusedproviding-aid-kills-west-papua

Elsham Papua (1999). Graves without names. Names without graves. Cited at www.biak.tribunal.org

Māori Television (MTS) (2015, September 26). West Papua: Native Affairs offers first NZ TV crew report for 50 years. Pacific Media Watch 9438. Retrieved at www.pmc.aut.ac.nz/pacific-mediawatch/west-papua-native-affairs-offersfirst-nz-tv-crew-report-50-years-9438

Pacific Media Centre Online (2011, October 20). Indonesian repression slated in new Pacific media freedom report. Retrieved at www.pmc.aut.ac.nz/articles/ west-papa-repression-reflected-newpacific-media-freedom-report

Peacock, Matt (2013, December 16). Searching for the truth about a massacre in West Papua. ABC 7.30 Report. Transcript retrieved at:www.abc.net.au/7.30/ content/2013/s3912701.htm

Perrottet, Alex \& Robie, David (2011). Pacific media freedom: A status report. Pacific Journalism Review, 17(2), 148186. Retrieved at www.pjreview.info/ articles/special-report-pacific-mediafreedom-2011-status-report-513

Perrottet, Alex \& Robie, David (2012). Pacific media freedom: A status report [Updated]. Pacific Journalism Monographs No 1. Retrieved at www. pmc.aut.ac.nz/research/pacific-mediafreedom-2011-status-report

Robie, David (2011, October 23). Papua a media black spot. New Matilda. Retrieved at https://newmatilda. com/2011/10/23/papua-media-blackspot/

Radio New Zealand (RNZ) (2015, October 28). Visit to West Papua. Retrieved at www.radionz.co.nz/national/programmes/nights/audio/201776455/ visit-to-west-papua 